\title{
The pollution prevention during the civil construction
}

\author{
Valery Azarov ${ }^{1, *}$, Svetlana Manzhilevskaya ${ }^{2}$, and Lubov Petrenko ${ }^{2}$ \\ ${ }^{1}$ Volgograd State Technical University, 400005, Lenin`s road, 28, Volgograd, Russia \\ ${ }^{2}$ Don State Technical University, 344010, Gagarin sq. 1, Rostov-on-Don, Russia
}

\begin{abstract}
The environmental protection is not only an important social problem, but also an efficiency increasing factor of construction operations. The problem of the environment preserving and the protecting people from the adverse health effects during the construction operations is growing more urgent due to the increase in volume of construction and the increasing availability of construction equipment. The works of many researchers are devoted to the study of the dust load and the evaluation of influence on the environment.This article describes the practical effect of air pollution during the construction site landscaping of two buildings, which are situated in Rostov-on-Don. Nowadays the limitation of air pollution emissions from construction operations is regulated by a number of normative documents, but civil designers, unfortunately, do not always meet the regulation of emissions in full obedience in the construction operating for a number of reasons. The correct environmental impact assessment from construction is possible, taking into account the sequence and simultaneity of the operations. It is especially important for the construction taken place on the territory of cities. According to the study, a set of measures for air pollution reduction was developed. Such measures can reduce the air pollution by $1.5-2$ times.
\end{abstract}

\section{Introduction}

The environmental protection is not only an important social problem, but also an efficiency increasing factor of construction operations. The environmental protection provides the decrease of the country's production resources consumption, the labor contribution, the natural resources consumption and capital productiveness, but it is followed by the extra construction workmanship costs and decrease of the social services investment.

The environmental pollution causes the economic damage due to the pollution-induced morbidity, the loss of productivity of land resources, the wear of fixed assets acceleration.

The problem of the environment preserving and the protecting people from the adverse health effects during the construction operations is growing more urgent due to the increase in volume of construction and the increasing availability of construction equipment.

\footnotetext{
* Corresponding author: oc41@bk.ru
} 
The works of Azarov VN, [2-8, 10-12, 15-16, 18, 21-24], Barikaeva N S, [15,18] , Trokhimchuk M V, [10, 16], Sidyakin, P.[27], Kyoyken M P [19], Menzelintseva N V [5, 26], Koshkarev S A [6,8,22], Solovyeva T V [9,11-15,17-18], Stefanenko I V [11,12,2124], Nikolenko D A [17,18], Sergina N M [ 21,23], Lozhkina, O V[ 25], Kalyuzhina, E. A.[28], Batmanov V P [7], Barratt B [20] and many others are devoted to the study of the dust load and the evaluation of influence on the environment.

This article describes the practical effect of air pollution during the construction site landscaping of two buildings, which are situated in Malinowski Street, 3 and Magnitogorskaya Street, 1, Rostov-on-Don. The subjects of this study were the construction site air pollution and indoor air pollution, at the workplace. The results of study were calculated with the help of Unified Program of air pollution estimation "Ecolog" 4.50 .

\section{Goal, tasks, methods of study}

The front-end engineering and construction of buildings which have direct and indirect impact on the environment, as well as during operation, abandonment and suspension of the building must be followed by the meeting of environment safety requirements, the nature protection activities development, rational use and the reproduction of natural resources, the improvement of the environment.

Nowadays the limitation of air pollution emissions from construction operations is regulated by a number of normative documents, but civil designers, unfortunately, do not always meet the regulation of emissions in full obedience in the construction operating for a number of reasons. For example, different operations can be carried out at different times; the technique cannot work simultaneously. The correct environmental impact assessment from construction is possible, taking into account the sequence and simultaneity of the operations. It is especially important for the construction taken place on the territory of cities.

The construction site works are carried out in two stages - pre-construction and main construction period.

There are 4 stages of the main construction period:

1. The substructure construction;

2. The superstructure construction;

3. The road construction works;

4. The landscaping and site finishing.

Two cases of air pollution emissions in Rostov-on-Don are considered during the landscaping works of the construction site. The first case is the air pollution of the 20storeyed residential house construction site in Malinowski Street, 3 in close proximity to the busy highway and the second case is the 25-story apartment construction site in Magnitogorskaya Street 1, located near the owner-occupied dwellings area. The results of air pollution concentration are calculated in accordance with standard methods.

Figure 1 and Figure 2 show the air contaminants emission rate diagrams at the landscaping and site finishing stage of both considered construction sites.

The air contaminants emission rate was determined by the total concentration of air contaminants and the regulatory concentration. 


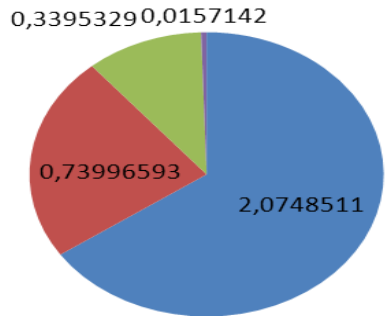

- Nitrogen dioxide-65\%

- Coal oil-23\%

- Inorganic dust-11\%

- Formaldehyde-1\%

Fig. 1. The air contaminants emission composite during the landscaping works at the construction site of the apartment house in Malinowski Street, 3, Rostov-on-Don

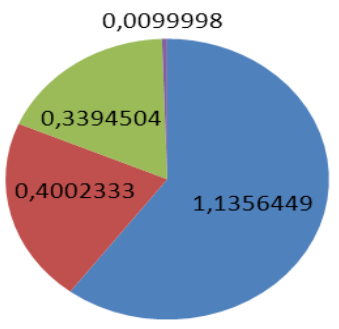

\author{
- Nitrogen dioxide-65\% \\ - Coal oil-23\% \\ - Inorganic dust-11\% \\ - Formaldehyde-1\%
}

Fig. 2. The air contaminants emission composite during the landscaping works at the construction site of the 25-story apartment house in Magnitogorskaya, 1, Rostov-on-Don

Figures 1 and 2 show that nitrogen oxide has the highest concentration in the air pollution. In the emissions from the landscaping works near the highway, the proportion of this contaminant reaches $65 \%$. It should be noted that significant substantial proportion in the emissions is the inorganic dust, particle size from 0.1 microns to 200 microns - $(11 \%)$. Also, there is a significant amount of coal oil $(23 \%)$ and formaldehyde $(1 \%)$ in both variants of the construction site location.

A comparative analysis of the calculations was carried out depending on the amount of emissions from all sources, the periods of maximum load for each substance and the choice of the necessary measures based on the analysis results.

The analysis of the dispersion calculations is given in Table 1.

Table 1. The calculations of dispersion of substances during the landscaping works.

\begin{tabular}{|c|c|c|c|c|c|}
\hline \multirow{2}{*}{$\begin{array}{l}\text { Name of the } \\
\text { source } \\
\text { emission }\end{array}$} & \multirow{2}{*}{$\begin{array}{l}\text { Name of the operation of } \\
\text { the pollutant emission } \\
\text { source }\end{array}$} & \multicolumn{2}{|c|}{ Polluting substance } & \multicolumn{2}{|c|}{$\begin{array}{c}\text { Polluting substance } \\
\text { emissions }\end{array}$} \\
\hline & & code & name & 1 st variant & $\begin{array}{l}2 \mathrm{nd} \\
\text { variant }\end{array}$ \\
\hline 1 & 2 & 3 & 4 & 5 & 7 \\
\hline \multirow{3}{*}{$\begin{array}{l}\text { 1 Dump truck } \\
\text { 2. Auto-trucks }\end{array}$} & \multirow[t]{3}{*}{ Stockpiling } & \multicolumn{4}{|l|}{$[\ldots]$} \\
\hline & & 0301 & $\begin{array}{l}\text { Nitrogen } \\
\text { dioxide }\end{array}$ & 0,0155778 & \\
\hline & & 2732 & Coal oil & 0,0092575 & \\
\hline \multirow{6}{*}{$\begin{array}{l}3 \text { Welding } \\
\text { operations } \\
4 \text { Compressed air } \\
\text { plant }\end{array}$} & \multirow[t]{2}{*}{ Site buildup } & \multicolumn{4}{|l|}{$[\ldots]$} \\
\hline & & 0301 & $\begin{array}{l}\text { Nitrogen } \\
\text { dioxide }\end{array}$ & 0,0885773 & 0,0885773 \\
\hline & \multirow{4}{*}{$\begin{array}{l}\text { Hard landscaping, } \\
\text { planting }\end{array}$} & \multicolumn{4}{|l|}{$[\ldots]$} \\
\hline & & 2732 & Coal oil & 0,0318531 & 0,0318531 \\
\hline & & 2908 & Inorganic dust & 0,3391427 & 0,3391427 \\
\hline & & 0301 & $\begin{array}{l}\text { Nitrogen } \\
\text { dioxide }\end{array}$ & 2,0748511 & 1,0470676 \\
\hline
\end{tabular}




\begin{tabular}{|c|c|c|c|c|}
\hline \multirow[t]{4}{*}{ Painting operations } & \multicolumn{3}{|l|}{$[\ldots]$} & \\
\hline & 1325 & Formaldehyde & 0,0157142 & 0,0099998 \\
\hline & 2732 & Coal oil & 0,69885533 & 0,3683802 \\
\hline & 2908 & Inorganic dust & 0,0003902 & 0,0003077 \\
\hline \multicolumn{2}{|c|}{ Total substances: 9} & & 3,27421923 & 1,8853284 \\
\hline
\end{tabular}

\section{Results and discussion}

The problem of air pollution control should be solved by taking account not only external atmospheric pollution, but also the reducing harmful emissions at the workplace during the construction operations such as reconstruction, renovation works, finishing works, because the workplace is also the atmospheric air of urban development. The priority pollutants of the air are dust, especially the fine dispersed dust. The fine dispersed dust measurement for these calculations was carried out in the air of construction sites and at the workplaces inside the building using dust aspirator PU-3E/12 according to standard methods. For PM10 and PM2.5 particulate loading estimation it was investigated fine dispersed dust in the air of the sanitary protection zone and the air at the workplaces produced by the following construction operations: the leveling walls after plastering, the batching of mortar, the wall chasing. The dust concentration was determined by the dust aspirator PU$3 \mathrm{E} / 12$ according to standard methods, and the fine dispersed dust composition, sampled during the repair, construction and finishing works, was investigated with the help of such equipment as Handheld 3016 IAQ Combo hand counter and CEL 712 Microdust pro real time dust monitor, for PC calculating it was used the program of digital scanned image processing DUST.

After the data handling the fine dispersed dust composition analysis showed that the dust particles PM10 and PM2.5 percentage, which is produced in the air of the urban environment and in the air at the workplaces of the repair, construction and finishing works has the following characteristics:

1. The batching of mortar operation has the proportion of particles PM10 and PM2.5, Dmax $20 \%-25 \%$ and $0.36 \%-0,5 \%$ from the total weight of particles respectively, to Dmax24-30 microns, respectively;

2. The wall chasing operation has the proportion of particles PM10 and PM2.5 - 38\% $40 \%$ and $0.4 \%-0,6 \%$ from the total weight of particles respectively to $20.5-25$ microns, respectively;

3. The leveling walls after plastering operation has the proportion of particles PM10 and PM2.5 -90\%-92\%, and 1.2\%-1,5\% from the total weight of particles respectively up to 12 microns, respectively.

The dust concentration inside the building under construction should not exceed the sanitary standards established by SN 245-71 [1]: the maximum one - time concentration of dust in the air $-0.5 \mathrm{mg} / \mathrm{m} 3$, the average daily- $0.15 \mathrm{mg} / \mathrm{m} 3$.

From the point of view of air purity, especially in cities, the environment is not ideal. And it happens due to the fact that external sources of dust are added also internal ones. External sources are emissions of transport, industrial enterprises, soil and sand particles, pollen, microorganisms.

It is fact that the construction site should be located far from the sources of pollutants, their emissions increase the sanitary protection zone. In order to avoid such a situation, as the location of the building near the highway, which is a significant source of harmful emissions, the constructible surfaces for residential and civil buildings should be located far away from such sources of pollution. 


\section{Summary}

According to the study, a set of measures for air pollution reduction was developed. Such measures can reduce the air pollution by 1.5-2 times. Since the construction site is usually selected away from the sources of severe impact on air pollution of urban areas, the assessment of the harmful effects must necessarily take into account in addition to the polluting processes of construction operations the pollution from vehicles. It is necessary to carry out sanitary requirements, technological measures and organizational arrangements for air pollution above the standard value prevention.

Sanitary requirements should establish MAC in the working zone area for a significant type of pollutants that have a fibrogenic effect.

Technological measures are most effective in the prevention of pollutant formation and emission. These measures include: the introduction of streamline production technology, in which there are no manually operated jobs; the automation and mechanization of construction operations involving the dust production; the construction operations development, the processing of dusty materials in a wet state; the long-distance control of construction operations; the dusty equipment pressurization and isolation, the operation of such equipment under vacuum; the local ventilation air outlet ports installation, exhaust or combined extract and input ventilation installation. Dust removal operations takes place directly from the places of dust generation.

Organizational arrangements can reduce the time spent in the workplace in conditions of increased air pollution. It is mandatory to conduct medical examinations of the workforce, suspend people with a number of chronic diseases from dusty operations. The correct worksite arrangement is also important. The correct work-site arrangement needs the usage of closed ways of transportation of the materials of construction, especially fine grade material transportation to the construction site and mechanization of certain construction operations, such as plastering, painting operations, lifting and load-lowering of goods, various individual protection means.

As a result of the study, the following measures were proposed to reduce emissions of harmful substances for the 2 construction sites under consideration.

During the plastering, caulking and batching works it was proposed to use the plaster machine PFT G5 SUPER. The principle of operation of the plaster machine PFT G5 SUPER is based on continuous preparation (stopper), the hard-wall plaster flow to the site work and applied to the surface to be treated in automatic mode building solutions on the basis of dry mixtures factory cooking. The dry mixture keeps in close bags and transportation of the solution is carried out by special high-strength close mortar hose. This equipment conducts the reduction of pollutant emission caused by the batching of mortars and also reduce the time spent in the workplace in conditions of increased air pollution.

To reduce the contact of people with fine grade material, compact vacuum equipment was proposed for unloading fine grade material and transporting them to the workplace with the help of the ducting hoses ZEPHIR S. The usage of these equipment especially important for suction of light industrial debris and dust, especially fine dispersed dust.

For painting works the spray-painting devices were applied, providing the mechanized preparation of the main types of painting compositions from dry mixes and semi-finished products, their submission to workplaces and drawing on the processed surface in the mechanized way.

The application of these equipments involves the reducing of $\mathrm{PM}_{10}$ and $\mathrm{PM}_{2.5}$ emissions at $13-15 \%$ during the construction. 


\section{References}

1. SN 245-71, Sanitary Regulations for Design of Industrial Facilities, USSSR (1972)

2. V.N. Azarov, D.P. Borovkov, A.M. Redhwan, International Review of Mechanical Engineering, 8, 750-753 (2014)

3. V. N. Azarov, D.V. Lukanin, D.P. Borovkov, A.M. Redhwan, International Review of Mechanical Engineering, 8, 851-856 (2014)

4. V.N. Azarov, I.N. Logachev, K.I. Logachev, Refractories and Industrial Ceramics, 55, 365-70 (2014)

5. V.N. Azarov, N.V. Menzelitseva, A.M. Redhwan, International Review of Mechanical Engineering, 6, 145-50 (2016)

6. S.A. Koshkarev, V.N. Azarov, Civil Engineering Magazine, 2, 18-32 (2015)

7. V.N. Azarov, A.I. Evtushenko, V.P. Batmanov, A.B. Strelyaeva, V.V. Lupinogin International Review of Mechanical Engineering, 7, 132-136 (2016)

8. V.N. Azarov, S.A. Koshkarev, D.V. Azarov, Procedia Engineering, 165, 1070-1079 (2016)

9. V.N. Azarov, T.V. Solovyova, Problems of industrial and environmental protection: a collection of materials and scientific publications by. engineers-ecologists, 7, 75-77 (2017)

10. V.N. Azarov, M.V. Trokhimchuk, O.P. Sidelnikova, Procedia Engineering, 150, 20082012 (2016)

11. I.V. Stefanenko, T.V. Solovyeva, M.H. Nasimi, V. N. Azarov, Applied Mechanics and Materials: Proc.of 2nd Int. Conf. on Civil, Architectural, Structural and Constructional Engineering, 878, 255-258 (2017)

12. I.V. Stefanenko, T.V. Solovyeva, M.H. Nasimi, V.N. Azarov, Applied Mechanics and Materials: Proc. of 3rd Int. Con.on Civil, Architectural, Structural and Constructional Engineering, 875, 132-136 (2018)

13. M.H. Nasimi, T.V. Solovyova, D.K.C Bataev, Engineering Journal of Don, 2 (2018)

14. M.H. Nasimi, T.V. Solovyova, Engineering Journal of Don, 2 (2017)

15. V.N. Azarov, N.S. Barikaeva, T.V. Solovyeva, Procedia Engineering, 150, 2001-2007 (2016)

16. V.N. Azarov, M.V. Trokhimchuk, A.K. Trokhimchuk, News Higher Educational. Institution. Geological. Exploration, 1, 55-59 (2016)

17. D.A. Nikolenko, T.V. Solovyeva, Engineering Journal of Don, 3 (2015)

18. V.N. Azarov, N.S. Barikaeva, T.V. Solovyeva, D.A. Nikolenko, Engineering Journal of Don, 4 (2015)

19. M.P. Kyoyken, Atmospheric Environment, 7, 26-35 (2013)

20. B. Barratt, D. Carslaw, G. Fuller, D. Green, A. Tremper, London Environmental Research Group Report, 11, 56 (2012)

21. V.N. Azarov, N.M. Sergina, I.V. Stefanenko, Applied Mechanics and Materials: Proc. of 3rd Int. Con., 875, 137-140 (2018)

22. S.A. Koshkarev, V.N. Azarov, I.V. Stefanenko, Applied Mechanics and Materials: Proc. of 3rd Int. Con., 875, 145-148 (2018)

23. I.V. Stefanenko, V.N. Azarov, N. M. Sergina, Applied Mechanics and Materials: Proc.of 2nd Int. Conf. on Civil, Architectural, Structural and Constructional Engineering, 878, 269-272 (2017) 
24. V.N. Azarov, I.V. Stefanenko, R.A. Burkhanova, Applied Mechanics and Materials: Proc.of 2nd Int. Conf. on Civil, Architectural, Structural and Constructional Engineering, 875, 187-190 (2018)

25. A.Vasilyev, V.Lozhkin, D.Tarkhov, O.Lozhkina, V.Timofeev, Journal of Physics: Conference Series (2017)

26. N.V. Menzelintseva, N.Y. Karapuzova, Y.S. Mikhailovskaya, A.M. Redhwan, International Review of Civil Engineering, 7(6), 192-195 (2016)

27. V. Azarov, N. Sergina, P. Sidyakin, I. Kovtunov, IOP Conference Series: Earth and Environmental Science, 90 (2015)

28. A.V. Azarov, N.S. Zhukovam, E.A. Kalyuzhina, Procedia Engineering, 150, 20802086 (2016) 